\title{
Elucidation of the mechanism of anti-herpes action of two novel semisynthetic cardenolide derivatives
}

\author{
Laurita Boff ${ }^{1}$. Naira Fernanda Zanchett Schneider ${ }^{1}$ Jennifer Munkert ${ }^{3}$. Flaviano Melo Ottoni ${ }^{2}$. \\ Gabriela Silva Ramos ${ }^{2} \cdot$ Wolfgang Kreis ${ }^{3} \cdot$ Fernão Castro Braga ${ }^{2} \cdot$ Ricardo José Alves $^{2} \cdot$ Rodrigo Maia de Pádua $^{2}$. \\ Cláudia Maria Oliveira Simões ${ }^{1}$ [
}

Received: 6 November 2019 / Accepted: 22 January 2020 / Published online: 29 April 2020

(c) Springer-Verlag GmbH Austria, part of Springer Nature 2020

\begin{abstract}
Human herpesviruses are among the most prevalent pathogens worldwide and have become an important public health issue. Recurrent infections and the emergence of resistant viral strains reinforce the need of searching new drugs to treat herpes virus infections. Cardiac glycosides are used clinically to treat cardiovascular disturbances, such as congestive heart failure and atrial arrhythmias. In recent years, they have sparked new interest in their potential anti-herpes action. It has been previously reported by our research group that two new semisynthetic cardenolides, namely $\mathbf{C 1 0}$ (3 $\beta$-[( $N-(2-$ hydroxyethyl)aminoacetyl]

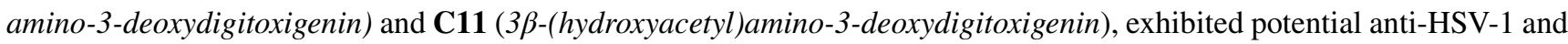
anti-HSV-2 with selectivity index values $>1,000$, comparable with those of acyclovir. This work reports the mechanism investigation of anti-herpes action of these derivatives. The results demonstrated that $\mathbf{C 1 0}$ and $\mathbf{C 1 1}$ interfere with the intermediate and final steps of HSV replication, but not with the early stages, since they completely abolished the expression of the UL42 $(\beta)$ and $\mathrm{gD}(\gamma)$ proteins and partially reduced that of ICP27 $(\alpha)$. Additionally, they were not virucidal and had no prophylactic effects. Both compounds inhibited HSV replication at nanomolar concentrations, but cardenolide $\mathbf{C 1 0}$ was more active than $\mathbf{C 1 1}$ and can be considered as an anti-herpes drug candidate including against acyclovir-resistant HSV-1 strains.
\end{abstract}

$\begin{array}{ll}\text { Abbreviations } \\ \text { ACV } & \text { acyclovir } \\ \text { CC }_{50} & 50 \% \text { cytotoxic concentration } \\ \text { CMC } & \text { carboxymethylcellulose } \\ \text { DEX-S } & \text { dextran sulfate } \\ \text { FBS } & \text { fetal bovine serum } \\ \text { HIV } & \text { human immunodeficiency virus } \\ \text { HSV-1 } & \text { herpes simplex virus type } 1 \\ \text { HSV-2 } & \text { herpes simplex virus type } 2 \\ \text { HPV } & \text { human papillomavirus }\end{array}$

Handling Editor: Zhongjie Shi.

Cláudia Maria Oliveira Simões

claudia.simoes@ufsc.br

1 Laboratório de Virologia Aplicada, Programa de Pós-Graduação em Farmácia, Universidade Federal de Santa Catarina (UFSC), Florianópolis, SC 88040-970, Brazil

2 Departamento de Produtos Farmacêuticos, Faculdade de Farmácia, Universidade Federal de Minas Gerais (UFMG), Belo Horizonte, MG 31270-901, Brazil

3 Pharmaceutical Biology, Department of Biology, Friedrich-Alexander-University Erlangen-Nuremberg, Erlangen, Germany

$\begin{array}{ll}\text { IC }_{50} & \begin{array}{l}\text { concentration that inhibited } 50 \% \text { of viral } \\ \text { replication }\end{array} \\ \text { MEM } & \text { Eagle's minimum essential medium } \\ \text { MOI } & \text { multiplicity of infection } \\ \text { PBS } & \text { phosphate-buffered saline } \\ \text { PFU } & \text { plaque-forming units } \\ \text { SI } & \text { selectivity index }\end{array}$

\section{Introduction}

Herpes simplex virus types 1 and 2 (HSV-1 and HSV-2) are alphaherpesviruses that infect humans. They have an enveloped icosahedral capsid containing a proteinaceous tegument and a linear DNA genome. For replication, it is necessary that the viruses adsorb and penetrate host cells to express $\alpha$ genes (immediate early phase), which mainly regulate viral replication, such as ICP27; $\beta$ genes (early phase), which are involved in synthesis and packaging of DNA, such as UL42; and $\gamma$ genes (late phase), which synthesize structural components of the virion, such as gD [1].

HSV-1 and HSV-2 infections are common and ubiquitous, with a considerable social impact independently of 
geographical region or population socioeconomic status, and are generally associated with ocular, orofacial and genital tract infections [2]. Most of the drugs used to treat herpesvirus infections are nucleoside analogs that share the same mechanism of action, affecting viral DNA synthesis by inhibiting viral DNA polymerase, such as acyclovir (ACV), the gold standard in the treatment of herpetic infections [3]. Such infections have become an important public health issue, mainly due to the HSV ability to cause acute and recurrent infections, as well as the emergence of resistant strains, which hinder the management of herpesvirus infections [4-6]. New anti-herpes drugs are therefore needed.

Cardenolides are cardiac glycosides mainly found in plant species, such as Nerium oleander L., Asclepias curassavica L. (Apocynaceae), Digitalis lanata Ehrh., and Digitalis purpurea L. (Plantaginaceae). These compounds have been used clinically for over 200 years to treat heart diseases [7] and are characterized by their powerful cardiotonic action [8]. The mechanism of their cardiotonic action occurs through the inhibition of $\mathrm{Na}^{+} / \mathrm{K}^{+}$-ATPase, involved in the $\mathrm{Na}^{+} / \mathrm{K}^{+}$ pump mechanism dependent on these ions, and promoting cardiac muscle contraction [9].

Despite the wide use of cardenolides as positive inotropic agents, the investigation of their effects on other pathologies has intensified in recent years, disclosing new potential therapeutic applications. Among them, their cytotoxic and antitumor effects recently reviewed by Cerella et al. [10], De et al. [11], Diederich et al. [12], Schneider et al. [13] and El-Seedi et al. [14], as well as their anti-inflammatory [15], antiprotozoal [16], anti-oxidant and anti-aging [17] activities can be cited. Another suggested possibility is their potential antiviral action, as reported by several authors against adenovirus [18], chikungunya virus [19], coronavirus [20, 21], cytomegalovirus [22-24], dengue virus [25], herpes virus [26-28], HIV [29-31], human papillomarivus (HPV) [32], influenza virus [33-35], and respiratory syncytial virus [36] replication. The effects of six well-known cardiac glycosides (digoxin, digitoxin, ouabain, convallatoxin, G-strophanthin and lanatoside C) on viral biology and the mechanisms by which they impair the replication of different RNA and DNA viruses were recently compiled [37]. Most of these studies only reported the antiviral activity of cardenolides, and it is required to understand the mechanistic aspects involved and how the compounds really act to further evaluate their potential therapeutic application.

As mentioned above, new antiviral therapies are currently needed, mainly for treating drug-resistant infections. In this sense, our research group had therefore conducted studies with natural [26] and semisynthetic cardenolides [38]. In previous work, we reported the semisynthesis of 16 new derivatives based on the scaffold of digitoxigenin and demonstrated their anti-HSV-1 (KOS and 29-R strains) and anti-HSV-2 (333 strain) activities. Two derivatives emerged as the most promising compounds from this screening - C10 $(3 \beta-[(N-(2-$ hydroxyethyl)aminoacetyl]amino-3-deoxydigitoxigenin) and C11 (3ß-(hydroxyacetyl)amino-3-deoxydigitoxigenin) - and they were selected in the present study for detailed investigation of the mechanism of their anti-HSV action.

\section{Materials and methods}

\section{Compounds, viruses and cell line}

C10 and C11 (Fig.1) were synthesized, and their chemical structures and purity were confirmed as described previously [38], within an ongoing Brazil-Germany bilateral partnership.

All assays were performed on Vero cells (ATCC: CCL81) grown in Eagle's minimum essential medium (MEM; Cultilab, Campinas, SP, Brazil) supplemented with $10 \%$ fetal bovine serum (FBS; Gibco, Carlsbad, CA, USA) and maintained at $37{ }^{\circ} \mathrm{C}$ in a humidified atmosphere containing $5 \% \mathrm{CO}_{2}$.

HSV-1 (KOS and 29-R strains, which are ACV-sensitive and ACV-resistant, respectively; Faculty of Pharmacy, University of Rennes I, Rennes, France) and HSV-2 (333 strain; Department of Clinical Virology, Göteborg University,

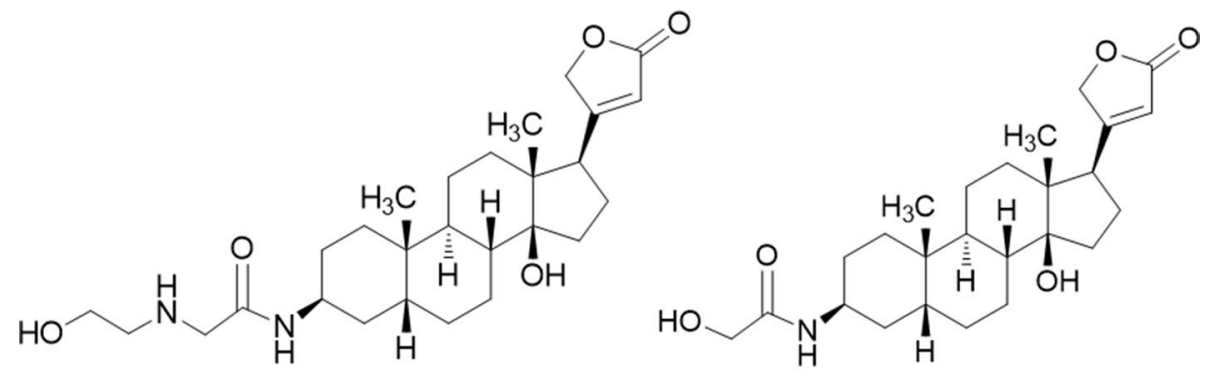

C10

C11

Fig. 1 Chemical structures of C10 and C11 
Göteborg, Sweden) viral stocks were propagated on Vero cells. They were titrated based on plaque-forming units (PFU), counted by plaque assay as described previously by Burleson et al. [39], and stored at $-80^{\circ} \mathrm{C}$.

\section{Evaluation of the anti-herpes mechanism of action}

C10 and C11 were selected for study based on their high selectivity indices $\left(\mathrm{SI}=\mathrm{CC}_{50} / \mathrm{IC}_{50}\right)$ obtained from antiherpes screening as reported by Boff et al. [38]. The elucidation of their mechanisms of action was performed using the assays described below.

\section{Plaque number reduction assay}

This assay was performed as described by Boff et al. [40]. Briefly, confluent cell monolayers $\left(2.5 \times 10^{5}\right.$ cells per well $)$ were infected with approximately $100 \mathrm{PFU}$ of each virus strain [HSV-1 (KOS and 29-R strains) and HSV-2 (333 strain)] for $1 \mathrm{~h}$ at $37^{\circ} \mathrm{C}$. Treatments were performed by adding non-toxic concentrations $(0.0625,0.125,0.25,0.5$ and $1.0 \mu \mathrm{M}$ ) of the samples after virus infection (post infection treatment). Cells were then washed with phosphate-buffered saline (PBS), overlaid with MEM containing 1.5\% carboxymethylcellulose (CMC; Sigma-Aldrich, St. Louis, MO, USA) in the presence or absence of the samples, and incubated for $48 \mathrm{~h}$. Cells were fixed and stained with naphthol blue-black (Sigma-Aldrich), and viral plaques were counted using a stereomicroscope. The concentration of each sample that reduced viral replication by $50 \%\left(\mathrm{IC}_{50}\right)$ when compared to untreated controls was estimated. Acyclovir (ACV) was used as a positive control.

\section{Virucidal assay}

This assay followed the procedures described by Silva et al. [41]. Mixtures of equal volumes of $\mathbf{C 1 0}$ and $\mathbf{C 1 1}$ at ten different concentrations $\left(1 / 5\right.$ to $\left.100 \times \mathrm{IC}_{50}\right)$ and $4 \times 10^{4} \mathrm{PFU}$ of HSV-1 or HSV-2 in serum-free MEM were co-incubated for 15 min at $4{ }^{\circ} \mathrm{C}$ or $37{ }^{\circ} \mathrm{C}$. $\mathbf{C 1 0}$ and $\mathbf{C 1 1}$ were then diluted to non-inhibitory concentrations (1:100) to determine the residual infectivity by plaque number reduction assay as described above.

\section{Pretreatment assay}

This assay was conducted as described by Bertol et al. [26]. Confluent cell monolayers were pretreated with ten different concentrations $\left(1 / 32\right.$ to $\left.5 \times \mathrm{IC}_{50}\right)$ of the samples for $3 \mathrm{~h}$ at $37^{\circ} \mathrm{C}$. Then, cells were infected with $100 \mathrm{PFU}$ of HSV-1 or
HSV-2 per well and treated as described above for the plaque number reduction assay. ACV was used as an internal control.

\section{Simultaneous treatment assay}

This assay was executed as described by Argenta et al. [42]. Confluent cell monolayers were infected with HSV-1 or HSV-2 with simultaneous addition of the samples at ten different concentrations $\left(1 / 32\right.$ to $\left.5 \times \mathrm{IC}_{50}\right)$. Further procedures are described above for the plaque number reduction assay. $\mathrm{ACV}$ was used as an internal control.

\section{Adsorption, post-adsorption and penetration assays}

These assays were performed following the general procedures described by Silva et al. [41]. Dextran sulfate (DEX-S; Sigma-Aldrich) was used as a positive control throughout the different assays. For the attachment assay, confluent cell monolayers were pre-chilled at $4{ }^{\circ} \mathrm{C}$ for $30 \mathrm{~min}$, exposed to a mixture of $100 \mathrm{PFU}$ of HSV-1 or HSV-2 per well in the absence (viral control) or presence of the samples at 10 different concentrations $\left(1 / 32\right.$ to $\left.5 \times \mathrm{IC}_{50}\right)$ and incubated at $4{ }^{\circ} \mathrm{C}$ for an additional $2 \mathrm{~h}$. Unabsorbed viruses were removed by washing with cold PBS; cells were overlaid with CMC medium and treated as described above for the plaque number reduction assay.

For the post-attachment assay, confluent cell monolayers were pre-chilled at $4{ }^{\circ} \mathrm{C}$ for 30 min and incubated with 100 PFU of HSV- 1 or HSV-2 per well at $4{ }^{\circ} \mathrm{C}$ for an additional $2 \mathrm{~h}$ to allow stable attachment of viruses without fusion with cell membranes. The samples were then added at 10 different concentrations $\left(1 / 32\right.$ to $\left.5 \times \mathrm{IC}_{50}\right)$, and the infected cells were incubated again at $4{ }^{\circ} \mathrm{C}$ for $2 \mathrm{~h}$ and treated as described above for the plaque number reduction assay.

For the penetration assay, $100 \mathrm{PFU}$ of HSV-1 or HSV-2 per well were adsorbed for $2 \mathrm{~h}$ at $4{ }^{\circ} \mathrm{C}$ onto confluent cell monolayers that had been pre-chilled at $4{ }^{\circ} \mathrm{C}$ for $30 \mathrm{~min}$ (at this temperature the viruses can bind but cannot penetrate the cells). Then, the temperature was shifted to $37{ }^{\circ} \mathrm{C}$ for $5 \mathrm{~min}$ to allow virus penetration, and the cells were treated with 10 different concentrations of the samples $\left(1 / 32\right.$ to $\left.5 \times \mathrm{IC}_{50}\right)$ and incubated for $1 \mathrm{~h}$ at $37{ }^{\circ} \mathrm{C}$. After incubation, unpenetrated viruses were inactivated with citrate buffer ( $\mathrm{pH} 3.0)$ for $1 \mathrm{~min}$. Cells were washed with PBS and treated as described above for the plaque number reduction assay.

\section{Western blot analyses}

To evaluate whether the compounds being tested interfere with HSV-1 (KOS strain) protein expression, experiments were performed following the procedures described by Argenta et al. [42]. Briefly, confluent cell monolayers were infected or not with HSV-1 at an MOI of 0.2 for $1 \mathrm{~h}$ 
at $37{ }^{\circ} \mathrm{C}$. Residual virus particles were then removed with PBS, and the cells were treated with five different concentrations of the samples $\left(1 / 16,1 / 8,1 / 4,1 / 2\right.$ and $\left.1 \times \mathrm{IC}_{50}\right)$ or $5 \mu \mathrm{M}$ of $\mathrm{ACV}$ (positive control) for $18 \mathrm{~h}$ (one viral replication cycle). The cells were then lysed, and protein quantification was carried out [43]. The protein content was separated electrophoretically in a $10 \%$ SDS-polyacrylamide gel and electroblotted onto nitrocellulose membranes (Schleicher \& Schuell, Dassel, Germany). After blocking, the membranes were incubated overnight with anti-ICP27 (1:1000, Millipore, Billerica, MA, USA), anti-UL42 (1:1000, Millipore), anti-gD (1:1000, Santa Cruz Biotechnology, Santa Cruz, CA, USA) and anti- $\beta$ actin antibodies (1:5000, Millipore). The last of these was used as a control for total protein loading. After washing, the membranes were incubated for $1 \mathrm{~h}$ with the respective secondary antibodies conjugated to horseradish peroxidase. Protein bands were revealed using Pierce Enhanced Chemiluminescence ECL Western Blotting substrate (Thermo Scientific, Rockford, IL, USA) according to the manufacturer's instructions. Images were acquired using a Bio-Rad ChemiDocTM MP System and digitalized using the program Image Lab, version 4.1. Relative densitometry data for the blots were analyzed using ImageJ free software.

\section{Viral release assay}

This assay followed the procedures described by Bertol et al. [26], and the percentages of inhibition were calculated according to Su et al. [28]. Briefly, confluent cell monolayers were infected with HSV-1 or HSV-2 at MOI 0.4 for $1 \mathrm{~h}$. Then, cell monolayers were washed, and different concentrations $\left(1 / 2,1\right.$ and $\left.2 \times \mathrm{IC}_{50}\right)$ of the samples were added to the cells for $24 \mathrm{~h}$ at $37^{\circ} \mathrm{C}$, after which the supernatants and cell pellets were collected separately. Pellets were frozen and thawed three times before virus titration by plaque number reduction assay as described above. Digitoxin (SigmaAldrich) was used as a positive control.

\section{Viral plaque size reduction assay}

This assay was conducted as described by Argenta et al. [42]. Different concentrations $(0.0625,0.125,0.25,0.5$ and $1 \mu \mathrm{M})$ of the samples were added to Vero cells after infection for $1 \mathrm{~h}$ with 100 PFU of HSV-1 or HSV-2. Further procedures were performed as described above for the plaque number reduction assay. After staining, images of 20 viral plaques formed in the presence or absence (viral control) of each concentration of the compounds were captured using a digital camera coupled to an Olympus IX71 inverted microscope
(Center Valley, PA, USA). The area of each viral plaque was determined using the ImageJ free software.

\section{Statistical analysis}

The mean values \pm standard deviations are representative of three independent experiments. Statistical analysis were performed by ANOVA followed by post-hoc tests as indicated.

\section{Results}

\section{Anti-herpes mechanism of action}

According to Boff et al. [38], the initial screening of 16 new cardenolide derivatives against HSV-1 (KOS and 29-R strains) and HSV-2 (333 strain) showed that C10 and C11 exhibited no relevant cytotoxic effects on Vero cells $(>300 \mu \mathrm{M})$ and displayed the highest antiviral potential $\left[\mathrm{IC}_{50}\right.$ values of C10 and C11, respectively: 0.23 and $0.24 \mu \mathrm{M}$ against HSV-1 (KOS strain); 0.18 and $0.19 \mu \mathrm{M}$ against HSV-1 (29-R strain); and 0.27 and $0.30 \mu \mathrm{M}$ against HSV-2 (333 strain)]. SI values were calculated based on their $\mathrm{CC}_{50}$ and $\mathrm{IC}_{50}$ values and found to be promising for both compounds. The SI values for C10 and C11 were as follows: HSV-1 (KOS strain) 1,304 and 1,250; HSV-1 (29-R strain) 1,667 and 1,579; HSV-2 (333 strain) 1,111 and 1,000, respectively. These values are similar to or even higher than those of acyclovir [HSV-1 (KOS strain) 1,449 and HSV-2 (333 strain) 619] [38].

\section{Virucidal activity}

Even at concentrations 100 times higher than their $\mathrm{IC}_{50}$ values, as described above [38], the treatments were not able to inactivate all virus strains tested (data not shown).

\section{Pretreatment effects}

Treatment of Vero cells with both compounds at $1 / 32$ to $5 \times$ $\mathrm{IC}_{50}$ before virus inoculation did not affect HSV-1 or HSV-2 replication, suggesting that they did not have prophylactic effects (data not shown).

\section{Effects on the early stages of viral replication}

In the same way, simultaneous treatment did not inhibit HSV replication, suggesting that the next steps of viral replication (adsorption, post-adsorption and penetration) were not 
affected. To confirme this finding, each of these steps was investigated individually, and the results confirmed that neither compound affected the early stages of viral replication (data not shown).

\section{Effects on the expression of viral proteins}

Since C10 and C11 did not interfere in the first steps of HSV-1 and HSV-2 replication, their effects on HSV-1 protein expression were evaluated by Western blot analyses. Fig. 2A shows a representative blot of the results obtained after $18 \mathrm{~h}$ of treatment (one HSV replication cycle) with $\mathbf{C 1 0}$ and $\mathbf{C 1 1}\left(1 / 16,1 / 8,1 / 4,1 / 2\right.$ and $\left.1 \times \mathrm{IC}_{50}\right)$ or $\mathrm{ACV}(5 \mu \mathrm{M})$, and Fig. $2 \mathrm{~B}$ shows the ratio of the amount of each viral protein to the amount of $\beta$-actin protein.

The compounds $\mathbf{C 1 0}$ (at concentrations of 1/4, 1/2 and $1 \times \mathrm{IC}_{50}$ ) and $\mathbf{C 1 1}$ (at concentrations of $1 / 2$ and $1 \times \mathrm{IC}_{50}$ ) completely abolished the expression of UL42 $(\beta)$ and $\mathrm{gD}(\gamma)$ proteins, and partially reduced that of ICP27 $(\alpha)$ in a concentration-independent manner (Fig. 2A).

\section{Effects on viral release}

The ability of $\mathbf{C 1 0}$ and $\mathbf{C 1 1}$ to interfere with virus release was investigated by determining the intra- and extracellular HSV-1 and HSV-2 titers. Fig. 3 shows that both compounds, at all tested concentrations, significantly reduced the extra- and intracellular titers of HSV. The highest activity was against HSV-1 (29-R strain). At $1 \times \mathrm{IC}_{50}$, virus release was inhibited by 97\% (C10), 96\% (C11) and 95\% (digitoxin, positive control).

\section{Effects on viral plaque size}

The effects of different concentrations of C10 and C11 on the cell-to-cell spread of HSV-1 and HSV-2 were evaluated using a viral plaque size reduction assay. As shown in Fig. 4A and B, when compared to viral control, both compounds significantly reduced the areas of the viral plaques that were formed. The strongest reduction detected (C10 from 79 to $100 \%$ and C11 from 73 to 100\%) was against HSV-1 (29-R strain), since the compounds almost completely closed the plaque area at the lowest concentration tested.

\section{Discussion}

The antiviral action is considered one of the new therapeutic possibilities of cardenolides besides their use as positive inotropic agents [44]. In the last decade, studies have highlighted these compounds as potent inhibitors of herpesvirus, as shown by Bertol et al. [26], Dodson et al. [27], and Su et al. [28]. Recently, our research group published the anti-herpes and cytotoxic screenings of 16 new semisynthetic cardenolides [38]. The compounds with the best anti-HSV potential were $\mathbf{C 1 0}$ and C11, and for this reason, several experiments were carried out to tentatively propose their mechanisms of action. In this study, both compounds were tested against HSV-1 (KOS and 29-R strains, which are $\mathrm{ACV}$-sensitive and ACV-resistant, respectively) and HSV-2 (333 strain).

One approach that has great potential applicability in the therapy of sexually transmitted diseases, including those caused by HSV, is the topical application of drugs that can permanently inactivate viral particles [45]. However, in this study, C10 and C11 were not able to inactivate HSV-1 and HSV-2. This indicates that these compounds do not act directly on viral particles before they entered into the cells, which agrees with the findings of studies performed with other cardenolides [26, 28, 46, 47].

In order to detect possible preventive effects, $\mathbf{C 1 0}$ and C11 were evaluated directly on Vero cells in the absence of the viruses. This approach also did not affect HSV replication, attesting that both compounds did not present prophylactic effects. These findings are in accordance with the results obtained by Bertol et al. [26] for glucoevatromonoside, a natural cardenolide.

Viruses and compounds were then added simultaneously to investigate if the initial phases of the HSV-1 and HSV-2 replication cycles were affected by $\mathbf{C 1 0}$ and $\mathbf{C 1 1}$. The results demonstrated that they did not act interfering with the early events of HSV infection, as it was confirmed posteriorly by the viral adsorption, post adsorption and penetration assays. These results are in line with the findings of the simultaneous treatment and corroborate the outcomes from Bertol et al. [26], Dodson et al. [27] and Su et al. [28].

It is well established that the HSV replication cycle is divided in six stages: adsorption, viral entry into host cells, expression of viral genes, DNA replication, assembly, and release of new viral particles $[2,48]$. The results obtained so far demonstrate that C10 and C11 do not affect the initial phases of HSV-1 and HSV-2 replication, do not inactivate these viruses, and have no prophylactic effects.

To identify the stages of the HSV replication cycle at which $\mathbf{C 1 0}$ and $\mathbf{C 1 1}$ could be acting, Western blot experiments were conducted. As already mentioned here, $\alpha$ genes regulate viral replication, $\beta$ genes are responsible for DNA synthesis and packaging, and $\gamma$ genes synthesize the structural components of the viruses [1]. Although both compounds gave promising results, $\mathbf{C 1 0}$ significantly reduced UL42 ( $\beta)$ and $\mathrm{gD}(\gamma)$ protein expression at a lower concentration than $\mathbf{C 1 1}$ and completely inhibited the expression of these proteins up to $1 / 4 \times \mathrm{IC}_{50}$. This suggests that $\mathbf{C 1 0}$ and $\mathbf{C 1 1}$ could interfere with the synthesis of viral DNA and structural components. Additionally, both compounds 
A
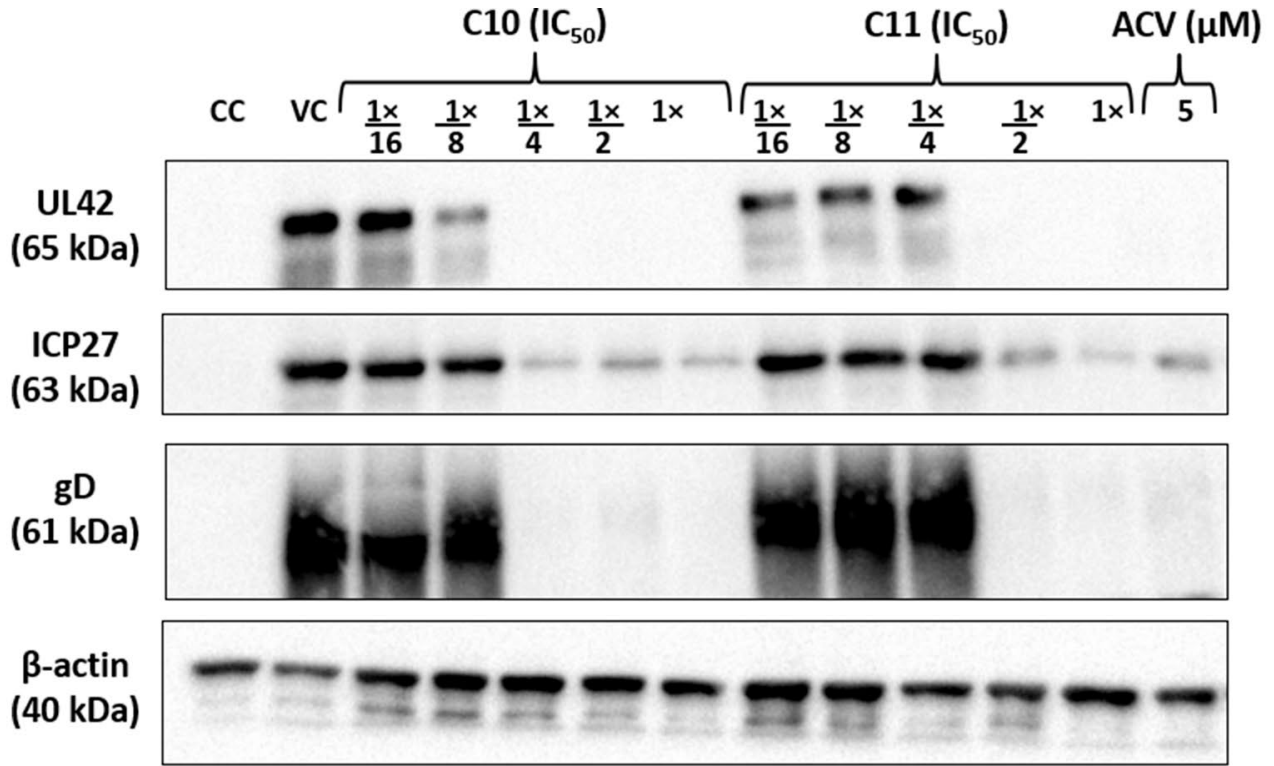

\section{B}
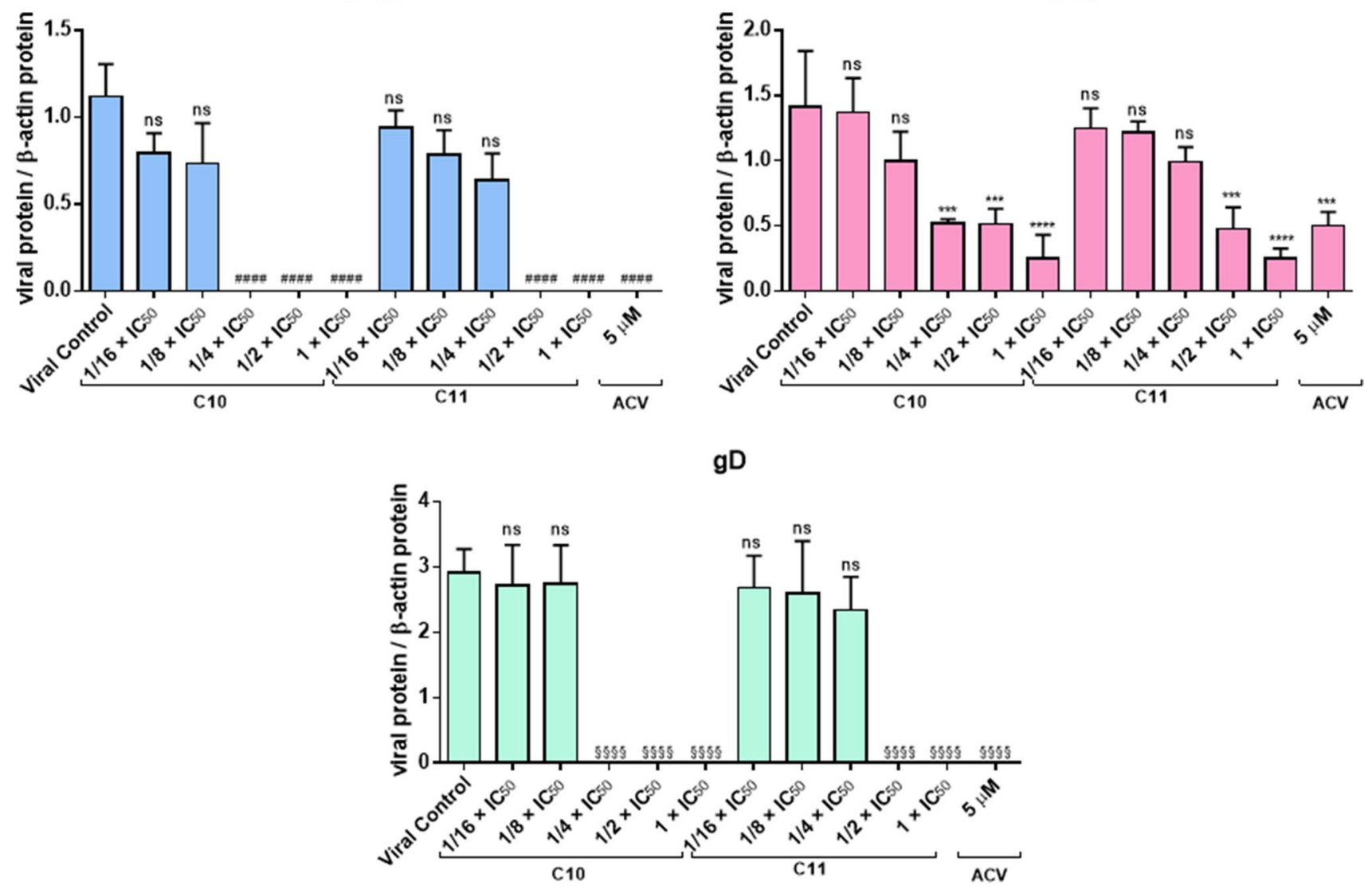

Fig. 2 Effects of $\mathbf{C 1 0}$ and $\mathbf{C 1 1}$ on HSV-1 (KOS strain) protein expression. (A) Confluent Vero cells were infected with HSV-1 (MOI 0.2 ) and treated with $1 / 16,1 / 8,1 / 4,1 / 2$ and $1 \times \mathrm{IC}_{50}$, or $5 \mu \mathrm{M}$ of ACV. Lysates were collected after $18 \mathrm{~h}$ of incubation, and the proteins were separated by SDS-10\% PAGE and analyzed using antibodies specific for the viral ICP27, UL42, and gD proteins. CC (cell control), uninfected and untreated Vero cells; VC (viral control), infected but not treated Vero cells; ACV, acyclovir. Equal protein loading was confirmed by probing for $\beta$-actin. (B) The graph indicates the ratio of the amount of each viral protein to that of $\beta$-actin. ns, not significant; \#\#\#\#, $p<0.0001$; ***, $p<0.001$; ****, $p<0.0001 ; \S \S \S \S, p<$ $0.0001 v s$. the respective viral controls (two-way ANOVA, Dunnett's post-hoc test) 

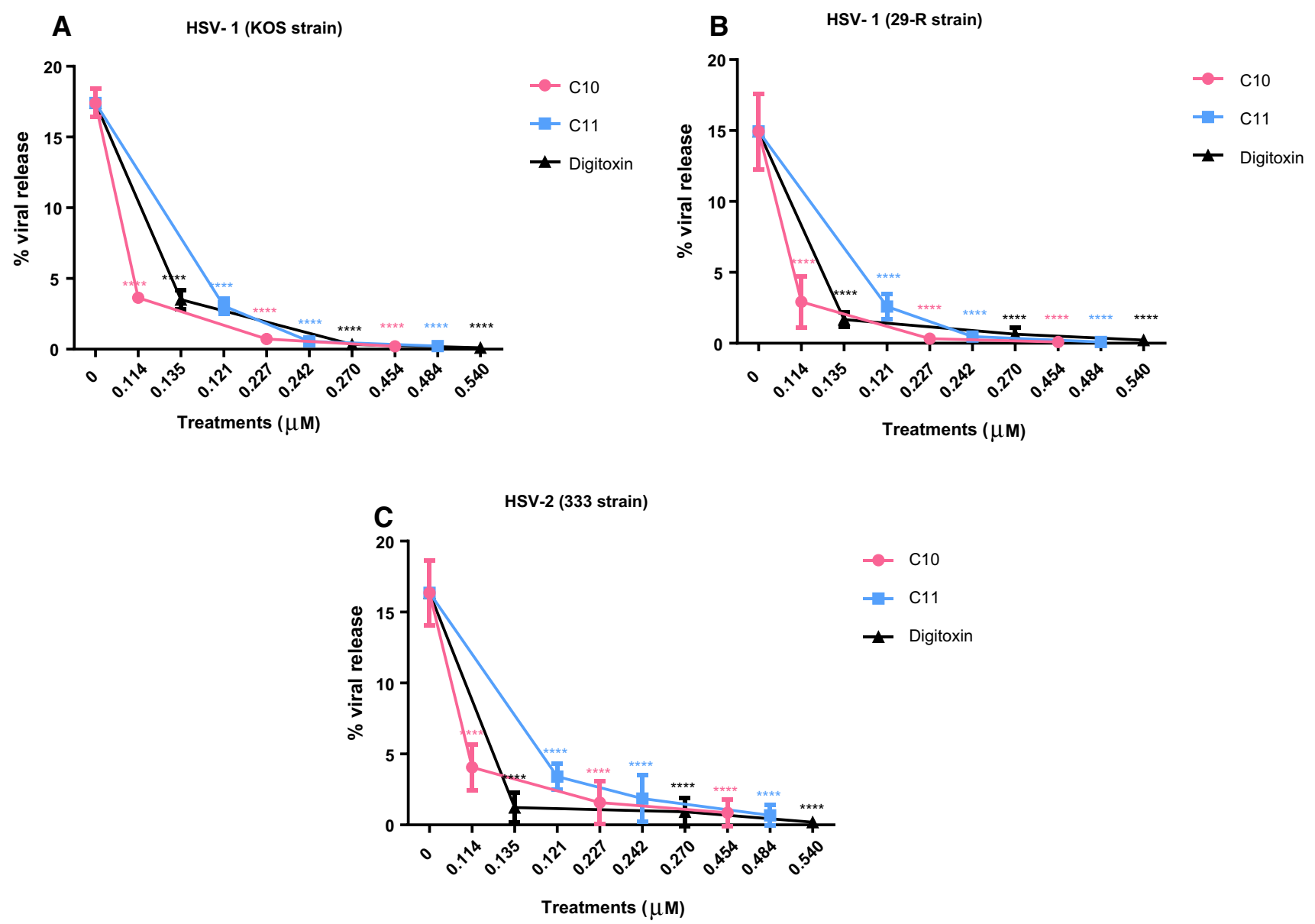

Fig. 3 Effects of $\mathbf{C 1 0}$ and $\mathbf{C 1 1}$ on virus release. Vero cells were infected with HSV-1 [(A) KOS and (B) 29-R strains] and (C) HSV-2 (333 strain) at MOI 0.4 for $1 \mathrm{~h}$. Cell monolayers were washed and treated with different concentrations $\left(1 / 2,1\right.$ and $\left.2 \times \mathrm{IC}_{50}\right)$ of $\mathbf{C 1 0}$, $\mathrm{C11}$ and digitoxin (positive control) for $24 \mathrm{~h}$ at $37^{\circ} \mathrm{C}$. The superna-

inhibited ICP27 $(\alpha)$ protein expression less than the other two proteins, but still significantly. At the molecular level, these results suggest that $\mathbf{C 1 0}$ and $\mathbf{C 1 1}$ interfere with the expression of all proteins evaluated, more intensively on the expression of early and late proteins in comparison with the immediate early proteins.

It is known that the genomic homology of HSV-2 is almost identical to that of HSV-1, and these viruses express the same proteins whose expression was evaluated in this work (gD, UL42 and ICP27) [49-51]. Earlier studies have shown that different samples, such as a cranberry extract [52] and a diterpene isolated from Andrographis paniculata Nees [53] were able to inhibit in a similar way the expression of these HSV-1 proteins as much as HSV-2 ones. Here, although the reduction of $\mathrm{gD}$, UL42 and ICP27 expression by $\mathbf{C 1 0}$ and $\mathbf{C 1 1}$ was only tested using HSV-1 (KOS strain), all other experiments were performed against both strains of HSV-1 (KOS and 29-R) and strain 333 of HSV-2. The tants and cell pellets were then collected separately. Pellets were frozen and thawed three times before virus titration by plaque number reduction assay. $* * * *, p<0.0001 v s$. the respective viral controls (two-way ANOVA, Dunnett's post-hoc test)

results showed similar inhibition profiles for all viral replication steps evaluated. Consequently, we presume that both compounds would act in the same way against HSV-1 (29-R strain) and HSV-2 replication by inhibiting the expression of the same proteins.

The capacity of $\mathbf{C 1 0}$ and $\mathbf{C 1 1}$ to block viral release was investigated by measuring the intra- and extracellular titers of HSV-1 and HSV-2. Both compounds reduced HSV release as much as the positive control (digitoxin), and for HSV-1 (29-R strain), this inhibition was greater than $80 \%$ at the lowest concentration tested. These results, together with those obtained by Western blot analyses, suggest that both compounds completely or partially inhibit the intermediate and final phases of HSV replication.

It is well established that the released viruses infect the adjacent cells of the infected tissues, replicate and continue to infect other cells through viral intercellular propagation (cell-to-cell spread), which is relevant to 
A

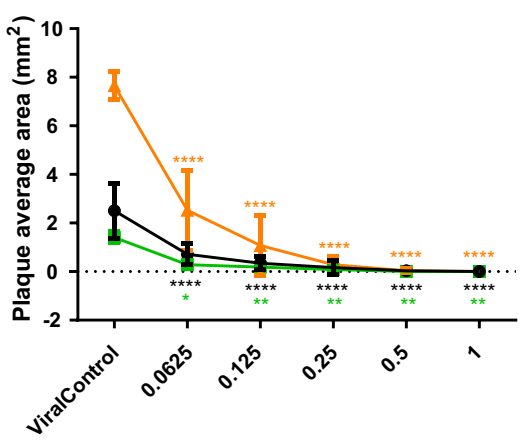

VC
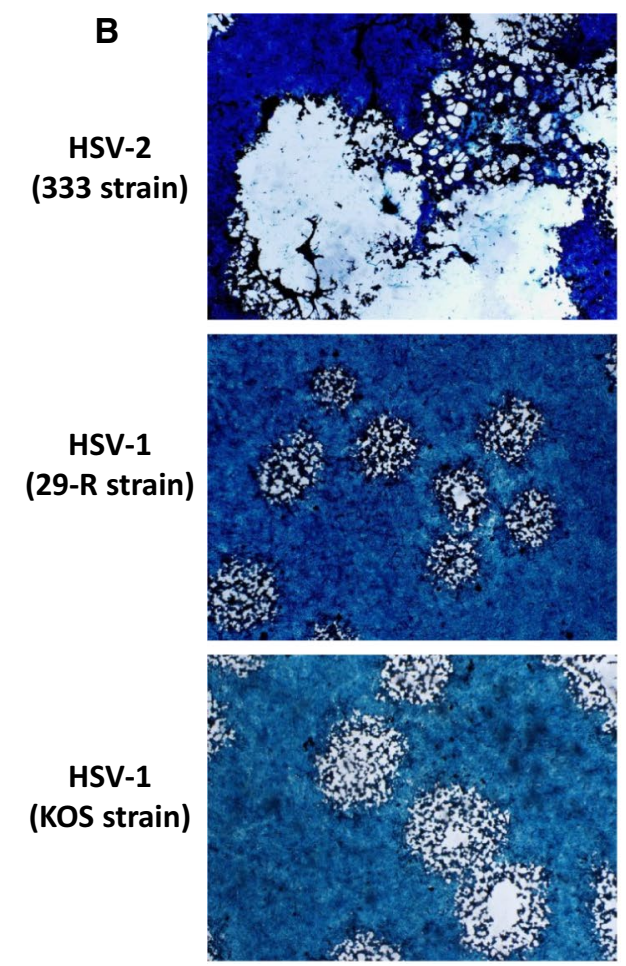

$\rightarrow$ HSV-2 (333 strain)

$\rightarrow$ HSV-1 (KOS strain)

- HSV-1 (29-R strain)
C11

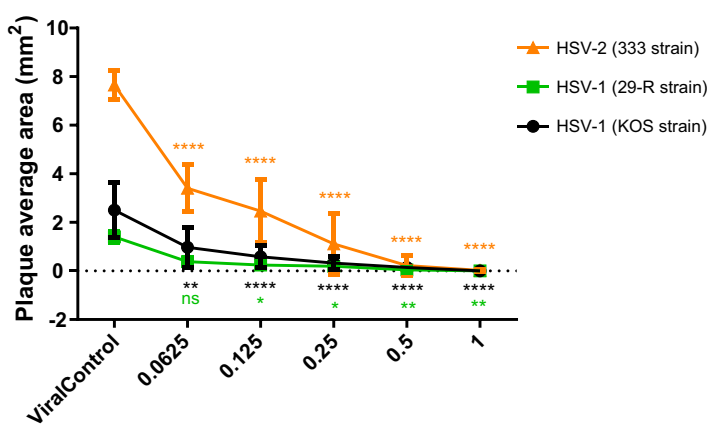

$\mathrm{C} 10(0.25 \mu \mathrm{M})$
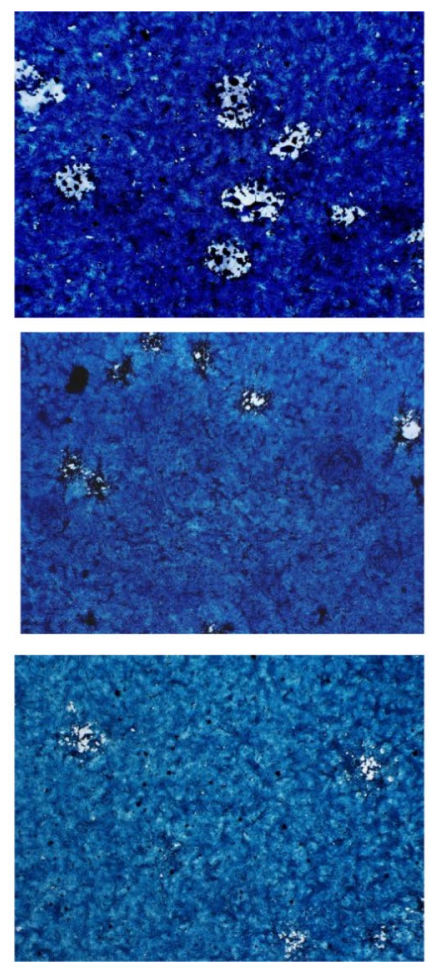

$\mathrm{C} 11(0.25 \mu \mathrm{M})$
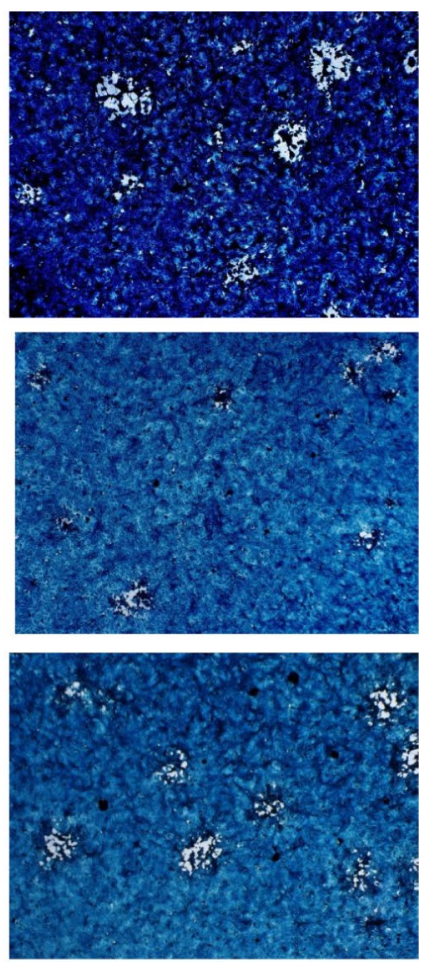

Fig. 4 Effects of $\mathbf{C 1 0}$ and $\mathbf{C 1 1}$ on viral plaque size of HSV-1 (KOS and 29-R strains) and HSV-2 (333 strain). (A) The areas of 20 lysis plates formed by the different viruses in the presence of the compounds $(0.0625$ to $1.0 \mu \mathrm{M})$ were measured, and (B) images formed in the presence and absence (viral control) of each concentration of C10 and C11 were captured. ns, not significant; *, $p<0.05$; **, $p<$ 0.01 ; and $* * * *, p<0.0001 v s$. the respective viral controls (two-way ANOVA, Dunnett's post-hoc test)

HSV replication would be inhibited, for example with transresveratrol, for which significant anti-HSV activity has also been described [69].

The mechanism by which cardenolides affect several steps of HSV replication could be related to the inhibition of $\mathrm{Na}^{+} /$ $\mathrm{K}^{+}$-ATPase in host cells. Many studies have demonstrated the modulation of $\mathrm{Na}^{+} / \mathrm{K}^{+}$-ATPase functions in host cells by DNA viruses (adenoviruses [18], cytomegalovirus [23, 70-72], and HSV [27, 28]), and RNA viruses (chikungunya virus $[19,73]$, coronaviruses $[20,74,75]$, respiratory syncytial virus [76, 77], Ebola virus [78, 79], influenza virus 
[33, 80, 81], and HIV [30, 31, 82]). By activating signaling cascades or by altering the concentration of intracellular ions, the binding of cardenolides to $\mathrm{Na}^{+} / \mathrm{K}^{+}$-ATPase seems to create an unfavorable environment for viral replication. Bertol et al. [26] showed that the inhibition of $\mathrm{Na}^{+} / \mathrm{K}^{+}$-ATPase caused by glucoevatromonoside was correlated with virus release and viral protein synthesis due to a reduction in the $\mathrm{K}^{+}$concentration in the cell. Cohen et al. [23] found that the inhibitory activity of cytomegalovirus replication by convallatoxin was due to a decrease in immediate-early gene expression and that the antiviral potency depends on the structure of cardiac glycosides and their specific interactions with $\mathrm{Na}^{+}$/ $\mathrm{K}^{+}$-ATPase. It was also shown that influenza virus replication was impaired by ouabain through the inhibition of viral protein translation and a decrease in the intracellular $\mathrm{K}^{+}$concentration [37]. Finally, Boff et al. [38] showed that $\mathbf{C 1 0}$ and C11 inhibited $\mathrm{Na}^{+} / \mathrm{K}^{+}$-ATPase, and a reduction in intracellular $\mathrm{K}^{+}$concentration could explain the inhibitory activity of those steps of viral infection. In summary, the main antiviral mechanisms suggested for both DNA and RNA viruses are decreased transcription of viral genes and impaired synthesis of viral proteins due to interference with the host translational machinery, such as the inhibition of $\mathrm{Na}^{+} / \mathrm{K}^{+}$-ATPase [37].

Structural differences among cardenolides, such as the substituents on the aglycone moiety and the number of sugars, may vary and alter their antiviral activity. Most of the cardenolides tested by Bertol et al. [26], Dodson et al. [27], and Su et al. [28] presented one or more sugar moieties bind to $\mathrm{C} 3$, unlike the cardenolides $\mathbf{C 1 0}$ and C11. Both of which have substituted amine groups at $\mathrm{C} 3$ and are able to inhibit HSV replication at nanomolar concentrations, but not with the same potency as cardenolides bearing sugars at C3. Thus, the sugar moiety, although not essential for anti-herpes activity, nevertheless influences this activity positively. Moreover, $\mathbf{C 1 0}$ was found to be more active than C11 in all experiments, and therefore, we hypothesize that the secondary amine group located on the side chain might also contribute to the antiviral activity. Consistent with this, Fytas et al. [83] and Tataridis et al. [84] showed that the presence of additional amino groups in adamantane derivatives increased their antiviral activity.

Even though previous works have addressed the antiherpes effects of different cardenolides, the investigation of the mechanism of anti-herpes action of C10 and $\mathbf{C 1 1}$ [HSV-1 (29-R strain) and HSV-2 (333 strain)] have not been explored so far, and we described it herein for the first time.

\section{Conclusions}

In conclusion, our findings suggest that $\mathbf{C 1 0}$ and $\mathbf{C 1 1}$ interfere mainly with the late steps of HSV replication, i.e., viral replication [HSV-1 (KOS strain)], assembling, release of new viruses and viral intercellular propagation [HSV-1 (KOS and 29-R strains) and HSV-2 (333 strain)]. In a minor extension, they also interfere with the intermediate stages of viral replication but not with the early steps. Additionally, they were not virucidal and have no prophylactic effects. These results encourage us to continue studying cardenolides as an alternative for the treatment of herpes simplex virus infections. Despite both compounds presented promising results, $\mathbf{C 1 0}$ was more potent with a lower $\mathrm{IC}_{50}$ value and the best selectivity index. Wherefore, they can be considered new bioactive molecules with great potential as anti-herpes drug candidates mainly for HSV-1 (29-R strain), which is resistant to $\mathrm{ACV}$ treatment.

Acknowledgements The authors thank the Brazilian funding agencies CAPES (MEC), Fapemig (APQ-00538-17, RMP) and CNPq (MCTI) for research fellowships, as well as $\mathrm{CNPq}$ for financial support (grant numbers 305878/2016-6, CMOS, and 490057/2011-0, FCB). They are also grateful to BAYLAT (JM and RMP for mobility support) and Marie Curie Foundation/European Community (FP7 IRSES, grant 295251, WK).

\section{Compliance with ethical standards}

Conflict of interest The authors declare that they have no conflict of interest.

\section{References}

1. Roizman B, Knipe DM, Whitley RJ (2013) Herpes simplex viruses. In: Knipe DM, Howley PM, Cohen JI, Griffin DE, Lamb RA, Martin MA, Racaniello VR, Roizman B (eds) Fields Virology. Lippincott Willians \& Wilkins, Philadelphia, pp 1823-1897

2. Kukhanova MK, Korovina AN, Kochetkov SN (2014) Human herpes simplex virus: life cycle and development of inhibitors. Biochemistry (Mosc) 79:1635-1652. https://doi.org/10.1134/ S0006297914130124

3. Mamidyala SK, Firestine SM (2006) Advances in herpes simplex virus antiviral therapies. Expert Opin Ther Pat 16:1463-1480. https://doi.org/10.1517/13543776.16.11.1463

4. Bacon TH, Levin MJ, Leary JJ, Sarisky RT, Sutton D (2003) Herpes simplex virus resistance to acyclovir and penciclovir after two decades of antiviral therapy. Clin Microbiol Rev 16:114-128. https://doi.org/10.1128/CMR.16.1.114-128.2003

5. Morfin F, Thouvenot D (2003) Herpes simplex virus resistance to antiviral drugs. J Clin Virol 26:29-37. https://doi.org/10.1016/ S1386-6532(02)00263-9

6. Roizman B, Whitley RJ (2013) An inquiry into the molecular basis of HSV latency and reactivation. Annu Rev Microbiol 67:355374. https://doi.org/10.1146/annurev-micro-092412-155654

7. Bessen HA (1986) Therapeutic and toxic effects of digitalis: William Withering, 1785. J Emerg Med 4:243-248. https://doi. org/10.1016/0736-4679(86)90048-X

8. Rahimtoola SH, Tak T (1996) The use of digitalis in heart failure. Curr Probl Cardiol 21:781-853. https://doi.org/10.1016/S0146 -2806(96)80001-6

9. Horisberger JD (2004) Recent insights into the structure and mechanism of the sodium pump. Physiology (Bethesda) 19:377387. https://doi.org/10.1152/physiol.00013.2004 
10. Cerella C, Dicato M, Diederich M (2013) Assembling the puzzle of anti-cancer mechanisms triggered by cardiac glycosides. Mitochondrion 13:225-234. https://doi.org/10.1016/j. mito.2012.06.003

11. De S, Banerjee S, Babu MN, Lakhmi BM, Babu TMS (2016) Review on cardiac glycosides in cancer research and cancer therapy. Indo Am J Pharm Res 6:5391-5400. https://doi. org/10.1044/1980-iajpr.150453

12. Diederich M, Muller F, Cerella C (2017) Cardiac glycosides: from molecular targets to immunogenic cell death. Biochem Pharmacol 125:1-11. https://doi.org/10.1016/j.bcp.2016.08.017

13. Schneider NFZ, Cerella C, Simões CMO, Diederich M (2017) Anticancer and immunogenic properties of cardiac glycosides. Molecules 22:E1932. https://doi.org/10.3390/molecules221119 32

14. El-Seedi HR, Khalifa SAM, Taher EA, Farag MA, Saeed A, Gamal M, Hegazy MF, Youssef D, Musharraf SG, Alajlani MM, Xiao J, Efferth T (2019) Cardenolides: Insights from chemical structure and pharmacological utility. Pharmacol Res 141:123175. https://doi.org/10.1016/j.phrs.2018.12.015

15. Zeitlin PL, Diener-West M, Callahan KA, Lee S, Talbot CC Jr, Pollard B, Boyle MP, Lechtzin N (2017) Digitoxin for airway inflammation in cystic fibrosis: preliminary assessment of safety, pharmacokinetics, and dose finding. Ann Am Thorac Soc 14:220 229. https://doi.org/10.1513/AnnalsATS.201608-649OC

16. Hoopes GM, Hamilton JP, Kim J, Zhao D, Wiegert-Rininger K, Crisovan E, Buell CR (2018) Genome assembly and annotation of the medicinal plant Calotropis gigantea, a producer of anticancer and antimalarial cardenolides. G3 (Bethesda) 8:385-391. https:// doi.org/10.1534/g3.117.300331

17. Xu J, Guo Y, Sui T, Wang Q, Zhang Y, Zhang R, Wang M, Guan S, Wang L (2017) Molecular mechanisms of anti-oxidant and anti-aging effects induced by convallatoxin in Caenorhabditis elegans. Free Radic Res 51:529-544. https://doi.org/10.1080/10715 762.2017.1331037

18. Grosso F, Stoilov P, Lingwood C, Brown M, Cochrane A (2017) Suppression of adenovirus replication by cardiotonic steroids. J Virol 91:e01623-16. https://doi.org/10.1128/JVI.01623-16

19. Ashbrook AW, Lentscher AJ, Zamora PF, Silva LA, May NA, Bauer JA, Morrison TE, Dermody TS (2016) Antagonism of the sodium-potassium ATPase impairs chikungunya virus infection. MBio 7:e00693-16. https://doi.org/10.1128/mBio.00693-16

20. Yang CW, Chang HY, Hsu HY, Lee YZ, Chang HS, Chen IS, Lee SJ (2017) Identification of anti-viral activity of the cardenolides, $\mathrm{Na}^{+} / \mathrm{K}^{+}$-ATPase inhibitors, against porcine transmissible gastroenteritis virus. Toxicol Appl Pharmacol 332:129-137. https://doi. org/10.1016/j.taap.2017.04.017

21. Yang CW, Chang HY, Lee YZ, Hsu HY, Lee SJ (2018) The cardenolide ouabain suppresses coronaviral replication via augmenting a $\mathrm{Na}^{+} / \mathrm{K}^{+}$-ATPase-dependent PI3K_PDK1 axis signaling. Toxicol Appl Pharmacol 356:90-97. https://doi.org/10.1016/j. taap.2018.07.028

22. Cai H, Wang HY, Venkatadri R, Fu DX, Forman M, Bajaj SO, Li H, O'Doherty GA, Arav-Boger R (2014) Digitoxin analogues with improved anticytomegalovirus activity. ACS Med Chem Lett 5:395-399. https://doi.org/10.1021/ml400529q

23. Cohen T, Williams JD, Opperman TJ, Sanchez R, Lurain NS, Tortorella D (2016) Convallatoxin-induced reduction of methionine import effectively inhibits human cytomegalovirus infection and replication. J Virol 90:10715-10727. https://doi.org/10.1128/ JVI.01050-16

24. Gardner TJ, Cohen T, Redmann V, Lau Z, Felsenfeld D, Tortorella D (2015) Development of a high-content screen for the identification of inhibitors directed against the early steps of the cytomegalovirus infectious cycle. Antiviral Res 113:49-61. https ://doi.org/10.1016/j.antiviral.2014.10.011
25. Cheung YY, Chen KC, Chen H, Seng EK, Chu JJ (2014) Antiviral activity of lanatoside $\mathrm{C}$ against dengue virus infection. Antiviral Res 111:93-99. https://doi.org/10.1016/j.antiviral.2014.09.007

26. Bertol JW, Rigotto C, Pádua RM, Kreis W, Barardi CR, Braga FC, Simões CMO (2011) Antiherpes activity of glucoevatromonoside, a cardenolide isolated from a Brazilian cultivar of Digitalis lanata. Antiviral Res 92:73-80. https://doi.org/10.1016/j.antiv iral.2011.06.015

27. Dodson AW, Taylor TJ, Knipe DM, Coen DM (2007) Inhibitors of the sodium potassium ATPase that impair herpes simplex virus replication identified via a chemical screening approach. Virology 366:340-348. https://doi.org/10.1016/j.virol.2007.05.001

28. Su CT, Hsu JT, Hsieh HP, Lin PH, Chen TC, Kao CL, Lee CN, Chang SY (2008) Anti-HSV activity of digitoxin and its possible mechanisms. Antiviral Res 79:62-70. https://doi.org/10.1016/j. antiviral.2008.01.156

29. Singh S, Shenoy S, Nehete PN, Yang P, Nehete B, Fontenot D, Yang G, Newman RA, Sastry KJ (2013) Nerium oleander derived cardiac glycoside oleandrin is a novel inhibitor of HIV infectivity. Fitoterapia 84:32-39. https://doi.org/10.1016/j.fitote.2012.10.017

30. Wong RW, Balachandran A, Ostrowski MA, Cochrane A (2013) Digoxin suppresses HIV-1 replication by altering viral RNA processing. PLoS Pathog 9:e1003241. https://doi.org/10.1371/journ al.ppat.1003241

31. Wong RW, Lingwood CA, Ostrowski MA, Cabral T, Cochrane A (2018) Cardiac glycoside/aglycones inhibit HIV-1 gene expression by a mechanism requiring MEK1/2-ERK1/2 signaling. Sci Rep 8:850. https://doi.org/10.1038/s41598-018-19298-x

32. Van Der Kolk T, Dillingh MR, Rijneveld R, Klaassen ES, Koning MNC, Kouwenhoven STP, Genders RE, Bouwes Bavinck JN, Feiss G, Rissmann R, Burggraaf J (2017) Topical ionic contraviral therapy comprised of digoxin and furosemide as a potential novel treatment approach for common warts. J Eur Acad Dermatol Venereol 31:2088-2090. https://doi.org/10.1111/jdv.14527

33. Hoffmann HH, Palese P, Shaw ML (2008) Modulation of influenza virus replication by alteration of sodium ion transport and protein kinase C activity. Antiviral Res 80:124-134. https://doi. org/10.1016/j.antiviral.2008.05.008

34. Kiyohara H, Ichino C, Kawamura Y, Nagai T, Sato N, Yamada H, Salama MM, Abdel-Sattar E (2012) In vitro anti-influenza virus activity of a cardiotonic glycoside from Adenium obesum (Forssk.). Phytomedicine 19:111-114. https://doi.org/10.1016/j.phyme d.2011.07.00

35. Amarelle L, Katzen J, Shigemura M, Welch LC, Cajigas H, Peteranderl C, Celli D, Herold S, Lecuona E, Sznajder JI (2019) Cardiac glycosides decrease influenza virus replication by inhibiting cell protein translational machinery. Am J Physiol Lung Cell Mol Physiol 6:L1094-L1106. https://doi.org/10.1152/ajplung.00173 .2018

36. Norris MJ, Malhi M, Duan W, Ouyang H, Granados A, Cen Y, Tseng YC, Gubbay J, Maynes J, Moraes TJ (2018) Targeting intracellular ion homeostasis for the control of respiratory syncytial virus. Am J Respir Cell Mol Biol 59:733-744. https://doi. org/10.1165/rcmb.2017-0345OC

37. Amarelle L, Lecuona E (2018) The antiviral effects of Na, K-ATPase inhibition: a minireview. Int J Mol Sci 19:E2154. https ://doi.org/10.3390/ijms19082154

38. Boff L, Munkert J, Ottoni FM, Schneider NFZ, Ramos GS, Kreis W, Andrade SF, Souza Filho JD, Braga FC, Alves R, Pádua RM, Simões CMO (2019) Potential anti-herpes and cytotoxic action of novel semisynthetic digitoxigenin-derivatives. Eur J Med Chem 167:546-561. https://doi.org/10.1016/j.ejmech.2019.01.076

39. Burleson FG, Chamberts TM, Wiedbrauk DL (1992) Virology: a laboratory manual. Academic, San Diego, p 250

40. Boff L, Silva IT, Argenta DF, Farias LM, Alvarenga LF, Pádua RM, Braga FC, Leite JP, Kratz JM, Simões CMO (2016) 
Strychnos pseudoquina A. St. Hil.: a Brazilian medicinal plant with promising in vitro antiherpes activity. J Appl Microbiol 121:1519-1529. https://doi.org/10.1111/jam.13279

41. Silva IT, Costa GM, Stoco PH, Schenkel EP, Reginatto FH, Simões CMO (2010) In vitro antiherpes effects of a C-glycosylflavonoid-enriched fraction of Cecropia glaziovii Sneth. Lett Appl Microbiol 51:143-148. https://doi.org/10.1111/j.1472765X.2010.02870.x

42. Argenta DF, Silva IT, Bassani VL, Koester LS, Teixeira HF, Simões CMO (2015) Antiherpes evaluation of soybean isoflavonoids. Arch Virol 160:2335-2342. https://doi.org/10.1007/s0070 5-015-2514-z

43. Bradford MM (1976) A rapid and sensitive method for the quantitation of microgram quantities of protein utilizing the principle of protein-dye binding. Anal Biochem 72:248-254. https://doi. org/10.1016/0003-2697(76)90527-3

44. Prassas I, Diamandis EP (2008) Novel therapeutic applications of cardiac glycosides. Nat Rev Drug Discov 7:926-935. https://doi. org/10.1038/nrd2682

45. Ekblad M, Adamiak B, Bergstrom T, Johnstone KD, Karoli T, Liu L, Ferro V, Trybala E (2010) A highly lipophilic sulfated tetrasaccharide glycoside related to muparfostat (PI-88) exhibits virucidal activity against herpes simplex virus. Antiviral Res 86:196-203. https://doi.org/10.1016/j.antiviral.2010.02.318

46. Hartley C, Hartley M, Pardoe I, Knight A (2006) Ionic contra-viral therapy (ICVT); a new approach to the treatment of DNA virus infections. Arch Virol 151:2495-2501. https://doi.org/10.1007/ s00705-006-0824-x

47. Nagai Y, Maeno K, Iinuma M, Yoshida T, Matsumoto T (1972) Inhibition of virus growth by ouabain: effect of ouabain on the growth of HVJ in chick embryo cells. J Virol 9:234-243

48. Colbère $F$ (1975) L'Herpèsvirus simplex: structure, réplication et biologie. Bull Inst Pasteur 73:203-254

49. Dasgupta G, Chentoufi AA, Kalantari M, Falatoonzadeh P, Chun S, Lim CH, Felgner PL, Davies DH, BenMohamed L (2012) Immunodominant "asymptomatic" herpes simplex virus 1 and 2 protein antigens identified by probing whole-ORFome microarrays with serum antibodies from seropositive asymptomatic versus symptomatic individuals. J Virol 86:4358-4369. https://doi. org/10.1128/JVI.07107-11

50. Davison AJ (2011) Evolution of sexually transmitted and sexually transmissible human herpesviruses. Ann NY Acad Sci 1230:E37E49. https://doi.org/10.1111/j.1749-6632.2011.06358.x

51. Park D, Lalli J, Sedlackova-Slavikova L, Rice SA (2015) Functional comparison of herpes simplex virus 1 (HSV-1) and HSV-2 ICP27 homologs reveals a role for ICP27 in virion release. J Virol 89:2892-2905. https://doi.org/10.1128/JVI.02994-14

52. Terlizzi ME, Occhipinti A, Luganini A, Maffei ME, Gribaudo G (2016) Inhibition of herpes simplex type 1 and type 2 infections by Oximacro®, a cranberry extract with a high content of A-type proanthocyanidins (PACs-A). Antiviral Res 132:154-164. https ://doi.org/10.1016/j.antiviral.2016.06.006

53. Priengprom T, Ekalaksananan T, Kongyingyoes B, Suebsasana S, Aromdee C, Pientong C (2015) Synergistic effects of acyclovir and 3, 19-isopropylideneandrographolide on herpes simplex virus wild types and drug-resistant strains. BMC Complement Altern Med 15:56. https://doi.org/10.1186/s12906-015-0591-x

54. Forsgren M, Klapper PE (2009) Herpes simplex virus type 1 and type 2. In: Zuckerman AJ, Banatvala JE, Schoub BD, Griffiths PD, Mortimer P (eds) Principles and practice of clinical virology, 6th edn. John Wiley \& Sons, Chichester, pp 95-131

55. Nyberg K, Ekblad M, Bergström T, Freeman C, Parish CR, Ferro V, Trybala E (2004) The low molecular weight heparan sulfatemimetic, PI-88, inhibits cell-to-cell spread of herpes simplex virus. Antiviral Res 63:15-24. https://doi.org/10.1016/j.antiv iral.2004.01.001
56. Astani A, Navid MH, Schnitzler P (2014) Attachment and penetration of acyclovir-resistant herpes simplex virus are inhibited by Melissa officinalis extract. Phytother Res 10:1547-1552. https:// doi.org/10.1002/ptr.5166

57. Cardozo FT, Camelini CM, Mascarello A, Rossi MJ, Nunes RJ, Barardi CR, Mendonça MM, Simões CMO (2011) Antiherpetic activity of a sulfated polysaccharide from Agaricus brasiliensis mycelia. Antiviral Res 92:108-114. https://doi.org/10.1016/j. antiviral.2011.07.009

58. Deethae A, Peerapornpisal Y, Pekkoh J, Sangthong P, Tragoolpua Y (2018) Inhibitory effect of Spirogyra spp. algal extracts against herpes simplex virus type 1 and 2 infection. J Appl Microbiol 124:1441-1453. https://doi.org/10.1111/jam.13729

59. Fernández Romero JA, Del Barrio AG, Alvarez RB, Gutiérrez Y, Valdés VS, Parra F (2003) In vitro antiviral activity of Phyllanthus orbicularis extracts against herpes simplex virus type 1. Phytother Res 17:980-982. https://doi.org/10.1002/ptr.1300

60. Gescher K, Hensel A, Hafezi W, Derksen A, Kühn J (2011) Oligomeric proanthocyanidins from Rumex acetosa L. inhibit the attachment of herpes simplex virus type-1. Antiviral Res 89:9-18. https://doi.org/10.1016/j.antiviral.2010.10.007

61. Ghosh M, Civra A, Rittà M, Cagno V, Mavuduru SG, Awasthi P, Lembo D, Donalisio M (2016) Ficus religiosa L. bark extracts inhibit infection by herpes simplex virus type 2 in vitro. Arch Virol 161:3509-3514. https://doi.org/10.1007/s0070 5-016-3032-3

62. Kesharwani A, Polachira SK, Nair R, Agarwal A, Mishra NN, Gupta SK (2017) Anti-HSV-2 activity of Terminalia chebula Retz extract and its constituents, chebulagic and chebulinic acids. BMC Complement Altern Med 17:110. https://doi.org/10.1186/s1290 6-017-1620-8

63. Lückemeyer DD, Müller VD, Moritz MI, Stoco PH, Schenkel EP, Barardi CR, Reginatto FH, Simões CMO (2012) Effects of Ilex paraguariensis A. St. Hil. (yerba mate) on herpes simplex virus types 1 and 2 replication. Phytother Res 26:535-540. https://doi. org/10.1002/ptr.3590

64. Ohta Y, Lee JB, Hayashi K, Hayashi T (2009) Isolation of sulfated galactan from Codium fragile and its antiviral effect. Biol Pharm Bull 32:892-898. https://doi.org/10.1248/bpb.32.892

65. Akanitapichat $P$, Wangmaneerat A, Wilairat P, Bastow KF (2006) Anti-herpes virus activity of Dunbaria bella Prain. J Ethnopharmacol 105:64-68. https://doi.org/10.1016/j.jep.2005.09.035

66. Hayashi K, Iinuma M, Sasaki K, Hayashi T (2012) In vitro and in vivo evaluation of a novel antiherpetic flavonoid, 4'-phenylflavone, and its synergistic actions with acyclovir. Arch Virol 157:1489-1498. https://doi.org/10.1007/s00705-012-1335-6

67. Lee S, Lee HH, Shin YS, Kang H, Cho H (2017) The anti-HSV-1 effect of quercetin is dependent on the suppression of TLR-3 in Raw 264.7 cells. Arch Pharm Res 40:623-630. https://doi. org/10.1007/s12272-017-0898-x

68. Sarkar S, Koga J, Whitley RJ, Chatterjee S (1993) Antiviral effect of the extract of culture medium of Lentinus edodes mycelia on the replication of herpes simplex virus type 1 . Antiviral Res 20:293-303. https://doi.org/10.1016/0166-3542(93)90073-R

69. Annunziata G, Maisto M, Schisano C, Ciampaglia R, Narciso V, Tenore GC, Novellino E (2018) Resveratrol as a novel anti-herpes simplex virus nutraceutical agent: an overview. Viruses 10:E473. https://doi.org/10.3390/v10090473

70. Cai H, Kapoor A, He R, Venkatadri R, Forman M, Posner GH, Arav-Boger R (2014) In vitro combination of anti-cytomegalovirus compounds acting through different targets: role of the slope parameter and insights into mechanisms of action. Antimicrob Agents Chemother 58:986-994. https://doi.org/10.1128/aac.01972 $-13$

71. Kapoor A, Cai H, Forman M, He R, Shamay M, Arav-Boger R (2012) Human cytomegalovirus inhibition by cardiac glycosides: 
evidence for involvement of the HERG gene. Antimicrob Agents Chemother 56:4891-4899. https://doi.org/10.1128/AAC.00898 $-12$

72. Mukhopadhyay R, Venkatadri R, Katsnelson J, Arav-Boger R (2018) Digitoxin suppresses human cytomegalovirus replication via $\mathrm{Na}^{+}, \mathrm{K}^{+} / \mathrm{ATP}$ ase $\alpha 1$ subunit-dependent AMP-activated protein kinase and autophagy activation. J Virol 92:e01861-17. https:// doi.org/10.1128/JVI.01861-17

73. Ganesan VK, Duan B, Reid SP (2017) Chikungunya virus: pathophysiology, mechanism, and modeling. Viruses 9:E368. https:// doi.org/10.3390/v9120368

74. Bailey ES, Fieldhouse JK, Choi JY, Gray GC (2018) A mini review of the zoonotic threat potential of influenza viruses, coronaviruses, adenoviruses, and enteroviruses. Front Public Health 6:104. https://doi.org/10.3389/fpubh.2018.00104

75. Burkard C, Verheije MH, Haagmans BL, Van Kuppeveld FJ, Rottier PJ, Bosch BJ, Haan CA (2015) ATP1A1-mediated Src signaling inhibits coronavirus entry into host cells. J Virol 89:4434 4448. https://doi.org/10.1128/JVI.03274-14

76. Cui R, Wang Y, Wang L, Li G, Lan K, Altmeyer R, Zou G (2016) Cyclopiazonic acid, an inhibitor of calcium-dependent ATPases with antiviral activity against human respiratory syncytial virus. Antiviral Res 132:38-45. https://doi.org/10.1016/j.antiv iral.2016.05.010

77. Stein RT, Bont LJ, Zar H, Polack FP, Park C, Claxton A, Borok G, Butylkova Y, Wegzyn C (2017) Respiratory syncytial virus hospitalization and mortality: Systematic review and meta-analysis. Pediatr Pulmonol 52:556-569. https://doi.org/10.1002/ppul.23570

78. Dowall SD, Bewley K, Watson RJ, Vasan SS, Ghosh C, Konai MM, Gausdal G, Lorens JB, Long J, Barclay W, Garcia-Dorival I, Hiscox J, Bosworth A, Taylor I, Easterbrook L, Pitman J, Summers S, Chan-Pensley J, Funnell S, Vipond J, Charlton S, Haldar J, Hewson R, Carroll MW (2016) Antiviral screening of multiple compounds against ebola virus. Viruses 8:E277. https://doi. org/10.3390/v8110277
79. Garcia-Dorival I, Wu W, Dowall S, Armstrong S, Touzelet O, Wastling J, Barr JN, Matthews D, Carroll M, Hewson R, Hiscox JA (2014) Elucidation of the Ebola virus VP24 cellular interactome and disruption of virus biology through targeted inhibition of host-cell protein function. J Proteome Res 13:5120-5135. https ://doi.org/10.1021/pr500556d

80. Hui EK, Nayak DP (2001) Role of ATP in influenza virus budding. Virology 290:329-341. https://doi.org/10.1006/viro.2001.1181

81. Mi S, Li Y, Yan J, Gao GF (2010) $\mathrm{Na}^{+} / \mathrm{K}^{+}$-ATPase $\beta 1$ subunit interacts with $\mathrm{M} 2$ proteins of influenza $\mathrm{A}$ and $\mathrm{B}$ viruses and affects the virus replication. Sci China Life Sci 53:1098-1105. https:// doi.org/10.1007/s11427-010-4048-7

82. Laird GM, Eisele EE, Rabi SA, Nikolaeva D, Siliciano RF (2014) A novel cell-based high-throughput screen for inhibitors of HIV-1 gene expression and budding identifies the cardiac glycosides. J Antimicrob Chemother 69:988-994. https://doi.org/10.1093/jac/ dkt471

83. Fytas C, Kolocouris A, Fytas G, Zoidis G, Valmas C, Basler CF (2010) Influence of an additional amino group on the potency of aminoadamantanes against influenza virus A. II - Synthesis of spiropiperazines and in vitro activity against influenza A H3N2 virus. Bioorg Chem 38:247-251. https://doi.org/10.1016/j.bioor g.2010.09.001

84. Tataridis D, Fytas G, Kolocouris A, Fytas C, Kolocouris N, Foscolos GB, Padalko E, Neyts J, De Clercq E (2007) Influence of an additional 2-amino substituent of the 1-aminoethyl pharmacophore group on the potency of rimantadine against influenza virus A. Bioorg Med Chem Lett 17:692-696. https://doi.org/10.1016/j. bmcl.2006.10.092

Publisher's Note Springer Nature remains neutral with regard to jurisdictional claims in published maps and institutional affiliations. 